\title{
Smartphone-Based Automated Non-Destructive Testing Devices
}

\author{
V.F. Petryk, A.G. Protasov, R.M. Galagan, A.V. Muraviov, I.I. Lysenko \\ National Technical University of Ukraine "Igor Sikorsky Kyiv Polytechnic Institute", \\ Peremohy Ave., 37, Kyiv 03056, Ukraine
}

Received 13.06.2020

Accepted for publication 30.11.2020

\begin{abstract}
Currently, non-destructive testing is an interdisciplinary field of science and technology that serves to ensure the safe functioning of complex technical systems in the face of multifactorial risks. In this regard, there is a need to consider new information technologies based on intellectual perception, recognition technology, and general network integration. The purpose of this work was to develop an ultrasonic flaw detector, which uses a smartphone to process the test results, as well as transfer them directly to an powerful information processing center, or to a cloud storage to share operational information with specialists from anywhere in the world.

The proposed flaw detector consists of a sensor unit and a smartphone. The exchange of information between the sensor and the smartphone takes place using wireless networks that use "bluetooth" technology. To ensure the operation of the smartphone in the ultrasonic flaw detector mode, the smartphone has software installed that runs in the Android operating system and implements the proposed algorithm of the device, and can serve as a repeater for processing data over a considerable distance (up to hundreds and thousands of kilometers) if it necessary.

The experimental data comparative analysis of the developed device with the Einstein-II flaw detector from Modsonic (India) and the TS-2028H+ flaw detector from Tru-Test (New Zealand) showed that the proposed device is not inferior to them in terms of such characteristics as the range of measured thicknesses, the relative error in determining the depth defect and the object thickness. When measuring small thicknesses from 5 to $10 \mathrm{~mm}$, the proposed device even surpasses them, providing a relative measurement error of the order of $1 \%$, while analogues give this error within $2-3 \%$.
\end{abstract}

Keywords: smartphone, ultrasonic flaw detection, wireless data transmission.

DOI: $10.21122 / 2220-9506-2020-11-4-272-278$

\begin{tabular}{l}
\hline Адрес для переписки: \\
В.Ф. Петрик \\
Национальный технический университет Украины \\
«Кевский политехнический институт имени Игоря Сикорского», \\
пр. Победы,, 37, г. Киев 03056, Украина \\
e-таil: vafереt@gтаil.com \\
\hline Для цитирования: \\
V.F. Petryk, A.G. Protasov, R.M. Galagan, A.V. Muraviov, I.I. Lysenko. \\
Smartphone-Based Automated Non-Destructive Testing Devices. \\
Приборы и методы измерений. \\
2020. - Т. 11, № 4. - С. 272-278. \\
DОI: 10.21122/2220-9506-2020-11-4-272-278 \\
\hline
\end{tabular}

\author{
Address for correspondence: \\ V.F. Petryk \\ National Technical University of Ukraine "Igor Sikorsky Kyiv \\ Polytechnic Institute", \\ Peremohy Ave., 37, Kyiv 03056, Ukraine \\ e-mail:vafepet@gmail.com \\ For citation: \\ V.F. Petryk, A.G. Protasov, R.M. Galagan, A.V. Muraviov, I.I. Lysenko. \\ Smartphone-Based Automated Non-Destructive Testing Devices. \\ Devices and Methods of Measurements. \\ 2020, vol. 11 , no. 4 , pp. $272-278$. \\ DOI: $10.21122 / 2220-9506-2020-11-4-272-278$
}




\section{Автоматизированные приборы неразрушающего контроля на базе смартфона}

\section{В.Ф. Петрик, А.Г. Протасов, Р.М. Галаган, А.В. Муравьёв, Ю.Ю. Лысенко}

Национальный технический университет Украинь

«Киевский политехнический институт имени Игоря Сикорского», пр. Победы, 37, г. Киев 03056, Украина

Поступила 13.06.2020

Принята к печати 30.11.2020

В настоящее время неразрушающий контроль является междисциплинарной областью науки и техники, служащей обеспечению безопасного функционирования сложных технических систем в условиях многофакторных рисков. В связи с этим возникает необходимость рассмотреть в этой области новые информационные технологии, основанные на интеллектуальном восприятии, технологии распознавания, повсеместной сетевой интеграции. Целью данной работы являлась разработка ультразвукового дефектоскопа, который использует смартфон для обработки результатов контроля, а также передачи их непосредственно в центр обработки информации, обладающий мощным оборудованием, или в облачное хранилище, что позволит получать доступ к оперативной информации для её изучения и обработки любому специалисту из любой точки мира.

Предложенный дефектоскоп состоит из сенсорного блока и смартфона. Обмен информацией между сенсором и смартфоном происходит с помощью беспроводных сетей, которые используют технологию «bluetooth». Для обеспечения работы смартфона в режиме ультразвукового дефектоскопа в смартфон инсталлировано программное обеспечение, которое работает в среде операционной системы Android и реализует предложенный алгоритм работы прибора, а при необходимости автоматически может выполнять роль ретранслятора для обработки данных на значительном расстоянии (до сотен и тысяч километров).

Сравнительный анализ экспериментальных данных разработанного устройства с дефектоскопом Einstein-II компании Modsonic (India) и дефектоскопом TS-2028H+ компании Tru-Test (New Zealand) показал, что предложенное устройство не уступает им по таким характеристикам, как диапазон измеряемых толщин, относительная погрешность определения глубины залегания дефекта и толщины объекта. При измерении малых толщин от 5 до 10 мм, предложенное устройство даже превосходит их, обеспечивая относительную погрешность измерения порядка $1 \%$, в то время как аналоги дают эту погрешность в пределах 2-3\%.

Ключевые слова: смартфон, ультразвуковая дефектоскопия, беспроводная передача данных.

DOI: $10.21122 / 2220-9506-2020-11-4-272-278$

Адрес для переписки:

В.Ф. Петрик

Национальный технический университет Украины

«Киевский политехнический институт имени Игоря Сикорского»,

пр. Победы, 37, г. Киев 03056, Украина

e-mail:vafepet@gmail.com
Address for correspondence:

V.F. Petryk

National Technical University of Ukraine "Igor Sikorsky Kyiv

Polytechnic Institute",

Peremohy Ave., 37, Kyiv 03056, Ukraine

e-mail:vafepet@gmail.com

\section{For citation:}

V.F. Petryk, A.G. Protasov, R.M. Galagan, A.V. Muraviov, I.I. Lysenko. Smartphone-Based Automated Non-Destructive Testing Devices.

Devices and Methods of Measurements.

2020, vol. 11, no. 4, pp. 272-278.

DOI: $10.21122 / 2220-9506-2020-11-4-272-278$ 


\section{Introduction}

The future of non-destructive testing (NDT) is closely related to processes characterized by higher accuracy, fewer errors and, therefore, an increased probability of detecting defects, as well as operational data that are available anytime from anywhere in space. The main problems of the NDT industry today include the following:

1. The equipment has complex user interfaces, so the process of system presetting and measurement is often complicated and laborious.

2. Having inefficient workflows, such as creating and marking a test grid on the investigating object. The accuracy of this process determines the precision of the sensor location on a given grid and, accordingly, the reliability of the testing result.

3. The complexity of the interpretation of the tomographic measurements data, which can vary significantly for different operators.

4. Great complexity of the testing procedure, which includes checking and calibrating sensors, documenting the measurement process and deviations from the prescribed procedure, interpreting the results, etc.

5. Complex data exchange between the NDT system's components. Considering that the volume of this data is constantly increasing, the problem arises of its storage and processing.

In this regard, it becomes necessary to consider NDT new information technologies based on intellectual perception, recognition technologies, ubiquitous network integration, etc. At present, the task is becoming actual wireless transmission of information from various types of primary converters to data collection and processing systems. Wireless data transmission makes it possible to automate this NDT system, simplifies the design of the device and makes it mobile, which makes it easier to test objects of a complex profile for the operator [1].

The prospects of using wireless communication for technical diagnostics with known NDT methods are considered in [2-3]. Such communication finds many applications in industry, for example, monitoring products during their manufacture [4], a system for detecting and locating insulation damage of a power transformer [5].

Work [6] presents a mobile system for ultrasonic signals processing using a smartphone for remote ultrasound testing and image processing. Using such developments, in [7-8], studies were carried out on the systems for monitoring the state of structures made based on smartphones. In [9-10], the results of testing systems using smartphones are presented, which are designed to monitor the movement, displacement, and tilt of building structures in dynamics. Smartphones can be used to monitor the internal displacement of structures during an earthquake [11]. Of particular interest is the work describing the use of a smartphone in aggregation and visualization techniques for continuous monitoring of transport infrastructure using the "crowd-sourcing" system [12]. A smartphone is used in medicine as structural systems for diagnosing diseases [13].

The authors [14] present the results of studies on the use of wireless technologies in NDT problems. A system for monitoring the state of metal structures is considered in [15], where a smartphone is used as a node for collecting data from wireless sensor networks based on Wi-Fi. Work [16] is devoted to a portable wireless spectrometer based on a smartphone for fast non-destructive testing of fruit ripeness. The device has a special application interface on a smartphone for communication, reception, construction and analysis of spectral data. The disadvantages of both devices are the limited use of the smartphone functionality, namely, the possibility of on-line data transmission over long distances for information processing using powerful equipment.

The purpose of this work is to develop an ultrasonic flaw detector using a smartphone for processing the test results, devoid of the above disadvantages. The use of a smartphone will allow automatic data transfer directly to an informationprocessing center with powerful equipment if it is impossible to make a decision on the results of onsite testing. The smartphone can also transfer data to the "cloud" storage, which will make it possible to access them for operational study and processing by any specialist from anywhere in the world.

\section{Ultrasonic flaw detector structure}

As a rule, ultrasonic (US) flaw detectors consist of two functional units: a transducer and an informationprocessing unit. The exchange of information between these units takes place most often using wireless networks that use Bluetooth technology. One of the disadvantages of this technology is the short information transmission range (within $10 \mathrm{~m}$ ). In addition, the range is highly dependent on obstacles and interference, even in the same room. This problem can be solved by using a separate sensor with a "Bluetooth" module and a smartphone. The 
sensor provides collection of primary information about the testing object and data transmission over short distances as separate data packets collected for a certain period of time or in the "Real-time" mode. The smartphone receives data packets from the sensor and can process them "on the spot" or, using GSM technology, transmit the data for further processing, generating a report or for drawing up a testing map. In practice, an ultrasound device consists of a sensor and a smartphone. Virtually, the device may include a server and a personal computer, which are located at a remote distance from the testing site.

The proposed flaw detector can also be used as an ultrasonic thickness gauge. The generalized block diagram of the proposed device is shown in Figure 1.

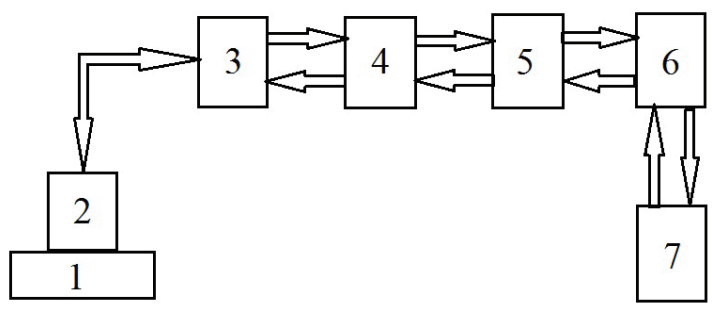

Figure 1-Generalized structural diagram of the flaw detector: 1 -testing object; 2 -electro-acoustic transducer; 3 - microcontroller; 4 - "Bluetooth" module; 5 - smartphone; 6 - server; 7 - personal computer

The developed sensor board includes a primary electroacoustic transducer, a microcontroller and a "Bluetooth" module. It works as follows: the signal from the primary converter goes to the analogto-digital converter (ADC), where it is converted into a digital code. Further, signal is transmitted via the UART (Universal Asynchronous ReceiverTransmitter) interface of the microcontroller to the "Bluetooth" module. The "Bluetooth" module, in turn, sends the received data for further processing to the smartphone. The smartphone has software installed for the testing procedure, which implements the proposed operation algorithm. This algorithm provides the received signal processes, generates reports with user settings and synchronizes with cloud services for data transfer. A smartphone can also act as a repeater for processing data over a considerable distance (up to hundreds and thousands of kilometers).

\section{Description of smartphone operation in ultrasonic thickness gauge mode}

As is known [17], the principle of an ultrasonic thickness gauge operation is based on the generation of short radio pulses with high-frequency filling into the test object (TO). The time interval between the leading edges of the radiation pulse and the pulse reflected from the TO opposite side will be proportional to the measured thickness.

To ensure the smartphone operation in the ultrasonic thickness gauge mode, a computer program has been proposed that runs in the Android operating system (version 8.0 and higher). The mandatory requirements for a smartphone are as follows: availability of wireless data transmission interfaces, such as: "Bluetooth", Wi-Fi, HDSPA + (3G) and LTE (4G). The start menu of the program allows you to check the smartphone for readiness to receive data from the sensor, and, if necessary, activate the "Bluetooth" module. The smartphone connection and selection menu allows you to connect it directly to the sensor "Bluetooth" module or to a remote server. When a smartphone connected to the sensor, you can see on the smartphone screen the image of electrical signals that come from the primary converter.

The program provides the ability to enter the propagation velocity of ultrasound in an object and select the necessary testing points to measure the time interval between two pulses. If there is a protector on the piezo transducer, the algorithm can take into account its thickness.

Choosing the points between the pulses (red dashed line) we can calculate the thickness of the TO (Figure $2 a$ ) or determine the distance to the defect (Figure 2b).
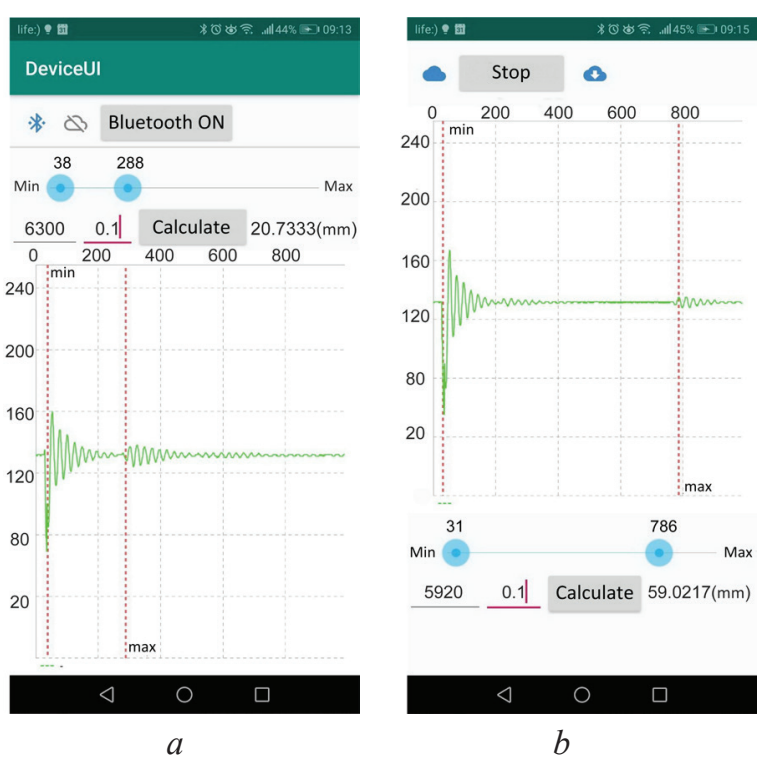

Figure 2 - The process of determining the thickness of the object $(a)$ and the distance to the defect $(b)$

If it is necessary to transmit testing data to a remote distance, the "receive data" option is used, 
which ensures the sensor connection to the server. In this case, the smartphone acts as a relay and transmits the received data to the cloud storage, from where the data can be accessed for processing by another device, for example, a computer or another smartphone.

\section{Experimental tests of the proposed device}

To confirm the efficiency of the proposed device, it was carried out a comparative analysis of the diagnostic data obtained for the developed MD-2 device and the TS-2028H+ and Eistein-II flaw detectors from Tru Test (New Zealand) and Modsonic (India), respectively.

During the research, the depth of the defect was determined, i. e. distance from the TO surface to the defect. In this case, both devices performed the function of a flaw detector. A sample with artificial defects made of SO-1 plexiglass (GOST 14782-86) was used as a test object. The measurements were carried out in the range from $5 \mathrm{~mm}$ to $60 \mathrm{~mm}$ with a step of $5 \mathrm{~mm}$. The relative error in the depth measuring of the defect was determined as comparative results (Figure 3).

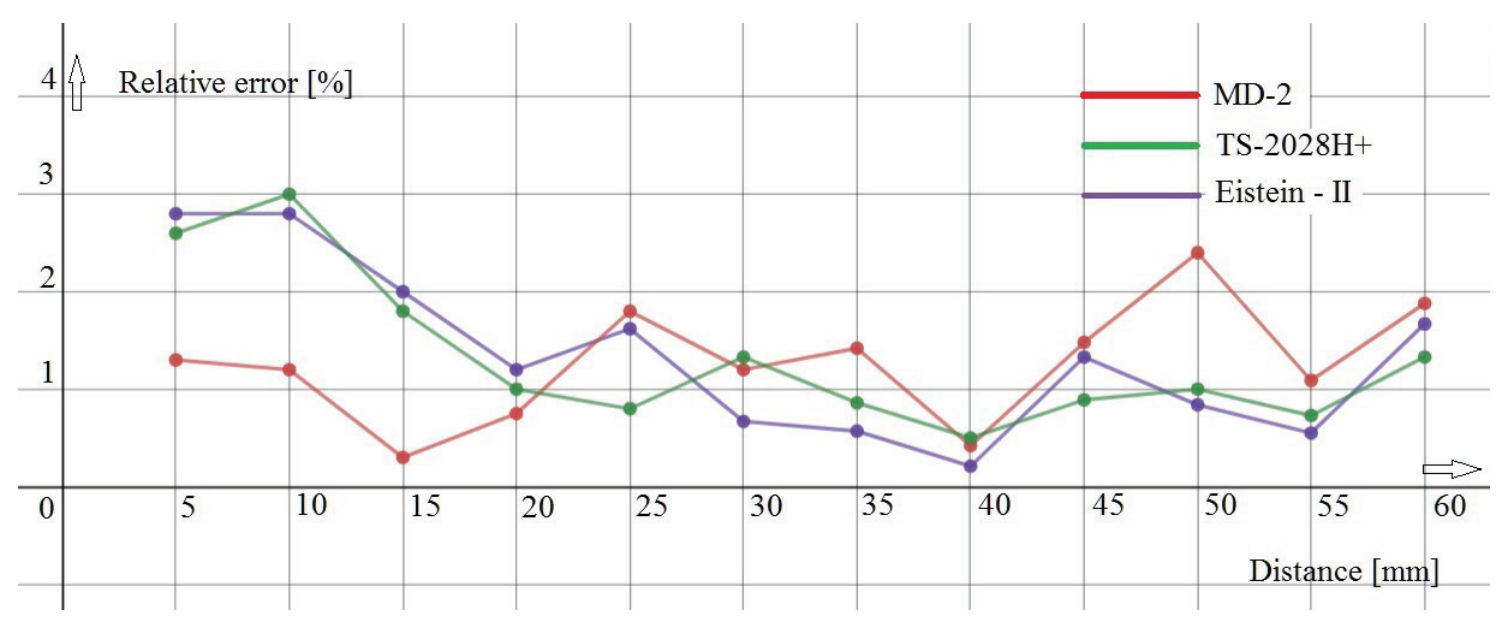

Figure 3 - Distribution of relative errors in measuring the defect depth

In addition, comparative tests of these devices were carried out when measuring the thickness of standard samples from aluminum. The measurement results are summarized in Table.

Table

Sample thickness measurement results

\begin{tabular}{lcccccc}
\hline & \multicolumn{2}{c}{ MD-2 } & \multicolumn{2}{c}{ TS-2028H+ } & \multicolumn{2}{c}{ Eistein-II } \\
\hline $\begin{array}{l}\text { Thickness, } \\
\text { mm }\end{array}$ & $\begin{array}{c}\text { Measurement } \\
\text { results, } \\
\text { mm }\end{array}$ & $\begin{array}{c}\text { Relative } \\
\text { error, \% }\end{array}$ & $\begin{array}{c}\text { Measurement } \\
\text { results, } \\
\text { mm }\end{array}$ & $\begin{array}{c}\text { Relative } \\
\text { error, \% }\end{array}$ & $\begin{array}{c}\text { Measurement } \\
\text { results, } \\
\text { mm }\end{array}$ & $\begin{array}{c}\text { Relative } \\
\text { error, \% }\end{array}$ \\
\hline 40 & 39.6 & 1 & 39.64 & 0.9 & 39.57 & 1.08 \\
20 & 20.15 & 0.75 & 19.83 & 0.85 & 19.78 & 1.1 \\
9 & 9.16 & 1.78 & 9.28 & 3.11 & 9.29 & 3.22 \\
5 & 5.23 & 4.6 & 5.16 & 3.2 & 5.17 & 3.4 \\
\hline
\end{tabular}

The graphs (Figure 3) and measurement results (Table) demonstrate that the developed MD-2 device is not inferior in its characteristics to foreign companies flaw detectors and even surpasses them in the near-field zone.

Due to the fact that during the measurements the peak of the echo pulse was determined by the operator manually, it is necessary to check the repeatability of the measurement results to obtain an empirical estimate of the distribution density of the random variable. Fifty measurements were carried out to provide it. As a sample was taken an object with a thickness of $40 \mathrm{~mm}$. A frequency histogram was constructed based on testing results (Figure 4). 


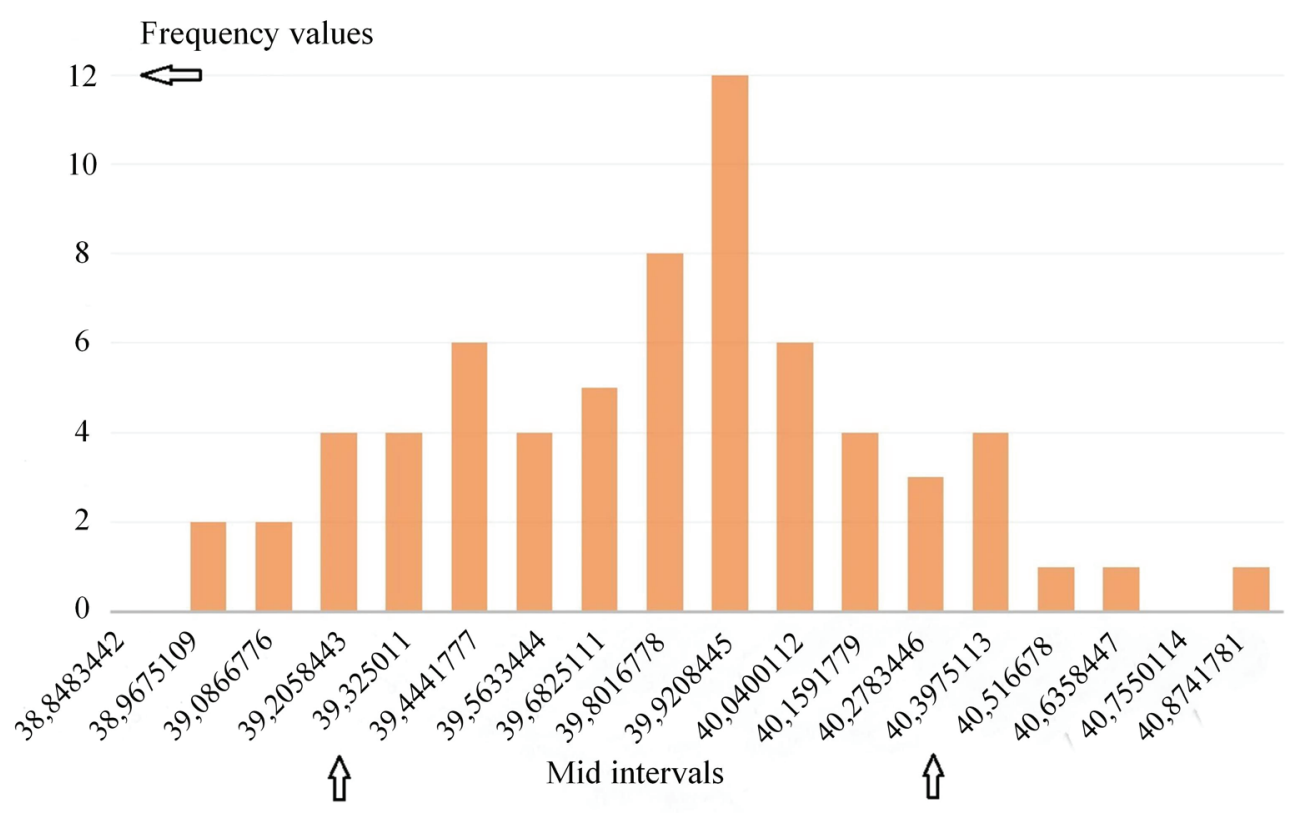

Figure 4 - Frequency histogram

The histogram demonstrates that the obtained measurement results obey the normal distribution law. This indicates that the measurement process is in a statistically controlled (stable) state. In this case, the variability of the process results is determined by the action of a system of random (general) causes only.

\section{Conclusion}

An ultrasonic flaw detector, consisting of a sensor unit and a smartphone, is presented. A sensor board has been developed, which includes a primary electroacoustic transducer, a microcontroller and a "Bluetooth" module. The exchange of information between the sensor and the smartphone takes place via a wireless network using "Bluetooth" technology. A software module has been developed in the Android operating system environment to ensure the operation of a smartphone in the ultrasonic flaw detector mode. The smartphone is equipped with software for the implementation of the testing procedure. This software realizes operation algorithm which provides the automatic transmission of testing data to an information processing center with powerful equipment or to a cloud service, which allows using data from anywhere in the world.

A comparative analysis of the experimental data of the developed device was carried out with the Einstein-II flaw detector from Modsonic (India) and the TS-2028H+ flaw detector from Tru-Test (New
Zealand) to confirm the efficiency of the proposed device. It is showed that the proposed device is not inferior to mentioned devices in such characteristics as the range of measured thicknesses, the relative error in determining of the defect depth and the object's thickness. When measuring small thicknesses from 5 to $10 \mathrm{~mm}$, the proposed device even surpasses them, providing a relative measurement error about $1 \%$, while analogues give this error within $2-3 \%$.

Further research will be aimed at developing software that will exclude the subjective factor of the operator and provide complete automation of the control process.

\section{References}

1. Baev A.R., Mayorov A.L., Asadchaya M.V., Konovalov G.E., Sergeeva O.S. Transformation and Scattering of Surface Waves on the Acoustic Load to Ultrasonic Evaluation and Measurements. Part 2. The object to study - solid with ledge. Devices and Methods of Measurements, 2018, vol. 9, no. 2, pp. 142-154.

DOI: $10.21122 / 2220-9506-2018-9-2-142-154$

2. Kren A.P., Delendyk M.N., Ivanov V.P. Industry 4.0: Transformations in Non-Destructive Testing. Science and innovation, 2019, no. 2 (192), pp. 28-32.

3. Meier J, Tsalicoglou I., Mennicke R. The future of NDT with wireless sensors, A.I. and IoT. Proceedings 15th Asia Pacific Conference for Non-Destructive Testing, Singapore, November 13-17, 2017, pp. 1-11.

4. El Kouche A., Hassanein H.S. Ultrasonic NonDestructive Testing (NDT) Using Wireless Sensor 
Networks. Procedia Computer Science, 2012, vol. 10, pp. 136-143. DOI: 10.1016/j.procs.2012.06.021

5. He X., Xie G., Jiang Y. Online Partial Discharge Detection and Location System Using Wireless Sensor Network. Energy Procedia, 2011, vol. 12, pp. 420-428.

DOI: $10.1016 /$ j.egypro.2011.10.056

6. Yi W., Gilliland S.S., Saniie J. Mobile ultrasonic signal processing system using Android smartphone. Circuits and Systems (MWSCAS), 2013 IEEE 56th International Midwest Symposium on, 4-7 August, 2013, pp. 1271-1274. DOI: 10.1109/MWSCAS.2013.6674886

7. Yu Y., Han R., Zhao X., Mao X., Hu W., Jiao D., Li M., Ou J. Initial validation of mobile-structural health monitoring method using smartphones. International Journal of Distributed Sensor Networks, February, 2015, pp. 1-14. DOI: 10.1155/2015/274391

8. Xie B., Li J., Zhao X. Research on Damage Detection of a 3D Steel Frame Model Using Smartphones. Sensors, 2019, vol. 19, no. 3, article №745.

DOI: $10.3390 / \mathrm{s} 19030745$

9. Han R., Zhao X., Yu Y., Guan Q., Hu W., Li M. A Cyber-Physical System for Girder Hoisting Monitoring Based on Smartphones. Sensors, 2016, Vol. 16, no. 7, article №1048. DOI: 10.3390/s16071048.

10. Morgenthal G., Höpfner H. The application of smartphones to measuring transient structural displacements. Journal of Civil Structural Health Monitoring, 2(3-4), 2012, no. 2, pp. 149-161.

DOI: $10.1007 / \mathrm{s} 13349-012-0025-0$

11. Li J., Xie B., Zhao X. Measuring the interstory drift of buildings by a smartphone using a feature point matching algorithm. Structural Control and Health Monitoring, January, 2020, pp. 1-17.

DOI: $10.1002 /$ stc. 2492
12. Seraj F.,Meratnia N.,Havinga P. An aggregation and visualization technique for crowd-sourced continuous monitoring of transport infrastructures. Pervasive Computing and Communications Workshops (Per Com Workshops), 2017 IEEE International Conference on, USA, March, 2017, pp. 1-6.

DOI: $10.1109 /$ PERCOMW.2017.7917561

13. Yu Y, Han R., Zhao X., Mao X., Hu W., Jiao D., Li M., Ou J. Initial Validation of Mobile-Structural Health Monitoring Method Using Smartphones. International Journal of Distributed Sensor Networks, February, 2015, pp. 1-14.

DOI: $10.1155 / 2015 / 274391$

14. Petryk V.F., Protasov A.G., Syeryy K.N., Povshenko A.A. Use of serial mobile devices when designing portable defectoscopes. Scientific notes of Taurida National V.I. Vernadsky University. Series: Technical Sciences, 2019, vol. 30 (69), p. 2, no.6, pp. 12-16.

DOI: $10.32838 / 2663-5941 / 2019.6-2 / 03$

15. Morgenthal G., Eick J.F., Rau S., Taraben J. Wireless Sensor Networks Composed of Standard Microcomputers and Smartphones for Applications in Structural Health Monitoring. Sensors, 2019, vol. 19, no. 9, article №2070. DOI: 10.3390/s19092070

16. Das A.J., Wahi A., Kothari I., Raskar R. Ultraportable, wireless smartphone spectrometer for rapid, nondestructive testing of fruit ripeness. Scientific Reports, 2016, vol 6 (1), pp. 32504-32512.

DOI: $10.1038 /$ srep32504

17. Ermolov I.N., Lange Yu.V. Nondestructive testing: Handbook: 7 vol. (ed. by V.V. Kluyev). Vol. 3, Ultrasonic Testing. M.: Publishing house Mashinostroenie, 2004, 864 p. 